\title{
Estimation of Carbon Dioxide and Carbon Stock of Vegetation along the Sukarno-Hatta Street Sides
}

\author{
Fatma M. Omar Abobsesa ${ }^{1}$, Arief Rachmansyah ${ }^{2}$, Amin Setyo Leksono ${ }^{3}$ \\ ${ }^{1}$ Post Graduate School of Environmental and Development, Graduate, Program, Brawijaya University \\ 2Department of Civil Engineering Department, Brawijaya University \\ ${ }^{3}$ Biology Department, Faculty of Mathematic and Science, Brawijaya University
}

\begin{abstract}
Carbon dioxide $\left(\mathrm{CO}_{2}\right)$ is an essential element of the atmosphere that is the basis of photosynthesis process and the vital component of body organism processes. However, if it rises above the normal level, it becomes the most serious cause of global warming. However, the growth of $\mathrm{CO}_{2}$ in the atmosphere has been slowed by the increase in the ability of plants to absorb the gas. This study is aimed to analyze $\mathrm{CO}_{2}$ emissions and plant absorption ability to discover carbon stock and carbon balance in the atmosphere. This study used a sample of human activities that contribute to $\mathrm{CO}_{2}$ emissions along the Soekarno-Hatta Street and the number of trees that soak the emissions. Remote sensing is applied to predict the levels of carbon dioxide emissions and absorption and carbon stocks. The absorption and stock of the carbon are calculated using a specific formula for biomass. The results showed a significant amount of carbon dioxide was emitted by motor vehicles passing through Soekarno-Hatta Street. However, only a small portion was generated by human activities carried out in stores, offices, restaurants, hotels, and hospitals. In line with that, the trees in the Soekarno-Hatta area were able to absorb carbon dioxide about 6 times higher than emitted. It also proved that the Palm tree (Roystonea regia) was capable of storing more carbon dioxide in significant amounts than the other two species, the Ashoka tree (Polyalthia longifolia), and the Rain tree (Samanea saman). Therefore, increasing the number of trees such as Palm tree in the area was recommended.
\end{abstract}

Keywords: Coaching strategy, Regency Adiwiyata, School management, Sintang Regency

\section{INTRODUCTION}

Increased concentrations of atmospheric carbon dioxide are the major threat to ecological balance. The imbalance leads to the increase in the surface temperature in the world by increasing the levels of carbon dioxide, methane and some other gases in the atmosphere. These gases are classified as greenhouse gases that cause the warming of the Earth's atmospheric surface, called global warming [1]. This phenomenon causes the melting of polar ice, the depletion of the ozone layer and the increase of UV radiation on the earth. This has resulted in climate and weather changes that adversely impact on the health and life of human biology [2].

Most of the increase in the atmospheric carbon dioxide concentrations in the atmosphere is due to human activities and transportation [2]. Industrial activities and the combustion of fossil fuels as energy sources rise the atmospheric carbon dioxide concentrations by approximately $35 \%$ since the start of the Industrial Revolution.

\footnotetext{
Correspondence address:

Amin Setyo Leksono

Email : amin28@ub.ac.id

Address : Biology Department, Faculty of Mathematic and
} Science, Brawijaya University
Because carbon dioxide dissolves in water, it appears naturally in ground water, lakes and rivers, on glaciers and ice caps, and also in seawater. It is liberated from carbonate rocks by dissolution in water and acids. It is also found in petroleum and natural gas deposits.

Global emission rose to its highest point in history to 34 billion metric tons (up 3\%). The rise of $2011 \mathrm{CO}_{2}$ emissions was beyond the increase in the last decade by $2.7 \%$. However, it was still lower than the 5\% increase in 2010. In Asia, Indonesia ranks $4^{\text {th }}$ as highest carbon emitter country after China, India and Japan [3]. Carbon emission increased from 373 ppm to 383 ppm during 2004 to 2010 [4].

However, the growth in the amount of $\mathrm{CO}_{2}$ in the Earth's atmosphere has been slowed by the increased ability of plants to absorb gas. A recent research report that green vegetation has helped offset most of the human-related carbon emissions between 2002 and 2014. Plants and trees become more absorbing due to the presence of extra $\mathrm{CO}_{2}$ in the atmosphere. The slowdown, however, cannot keep up with the overall emission scale. Over the past 50 years, the amount of $\mathrm{CO}_{2}$ absorbed by the oceans, plants and vegetation of the earth has doubled and these carbon sinks now account for about $45 \%$ of 
the gas emitted each year due to human activities. Researchers have recently reported that since the beginning of the 21st century, there has been a significant change in the amount of carbon dioxide taken by plants and trees. Recent studies show that between 2002 and 2014, terrestrial carbon sinks are increasing. There has been a recent pause in atmospheric $\mathrm{CO}_{2}$ growth rates and a decrease in anthropogenic emission fractions that remain in the atmosphere. The decrease was associated with increased $\mathrm{CO}_{2}$ in the atmosphere in vegetation [5].

The study area is the Soekarno Hatta Street. The street is about 1.7 kilometers from the Brawijaya University to Permata Jingga residence. It is a main and multi-residential service area and city street and has many restaurants, hotels, shops and beauty shops, auto repair and showroom. There are many services on the street sides because of which it is called Student Roads and local service. The street is always on the move from all means of transportation using fuel causing air pollution consisting of many gases, including carbon dioxide.

\section{RESEARCH METHOD}

Calculate the Total of Carbon Dioxide Emission

The formula for each calculation is as follows:

Average carbon dioxide emission produced in the restaurants: Number of restaurant $x$ number of people $x$ carbon daily

$$
\mathrm{Er}=\mathrm{n} \times \mathrm{a} \times 0.48 \mathrm{~m} 3 \ldots . .1
$$

Average carbon dioxide emission produced in the shop: Number of shop $x$ number of people $x$ carbon daily.

$$
\mathrm{Es}=\mathrm{n} \times \mathrm{a} \times 0.48 \mathrm{~m} 3 \ldots .2
$$

Average carbon dioxide emission produced in the office: (number of office $x$ number of worker $x$ carbon daily) + (number of office $x$ number of customers $x$ carbon daily).

$E o=(n \times a 1 \times 1.04 m 3)+(n \times a 2 \times 0.64 m 3) .3$

Average Carbon dioxide emission produced in the hotel: (number of hotel $x$ number of workers $x$ carbon daily) + (number of hotel $x$ number of guests $x$ carbon daily).

$$
E h=(n \times a 1 \times 3.12 m 3)+(n \times a 2 \times 0.312 m 3) . .4
$$

Average carbon dioxide emission produced in the hospital: (number of hospital $x$ number of workers $x$ carbon daily) + (number of hospital $x$ number of patients $x$ carbon daily).

$$
E h=(n \times a 1 \times 3.12 m 3)+(n \times a 2 \times 0.312 m 3) . .5
$$

Average Carbon dioxide emission produced in the traffic: (number of cars and motor cycles $\mathrm{x}$ carbon daily) + (number of trucks, buses, and mini buses $x$ carbon daily)

$$
\mathrm{Et}=(\mathrm{n} 1 \times 11.934 \mathrm{~kg})+(\mathrm{n} 2 \times \mathrm{a} 2 \times 12.078 \mathrm{~kg}) . .6
$$

\section{Data Analysis}

Using remote sensing to estimate carbon stocks

The study of the use of remote sensing to measure the stock of carbon in terrestrial systems has been done before $[6,7]$. Remote sensing usually gives spatial information of the size and landscape of the areas. On the other hand, the inventory information is commonly focused on small areas of plots. Using remote sensing, carbon sinks can be calculated by applying the values of carbon density from landscape data or national forest inventories over the land covering vegetation maps.

\section{Sampling Design:}

The samples were taken from the SoekarnoHatta street location. The street is as long as 1.760 meters. From this location, the population was allocated into 2 different spaces, green belt and green open space. Field surveys were conducted in February 2017, 8 plots of $100 \mathrm{~m} \times 3 \mathrm{~m}$ were randomly allocated to the intact, transformed and degraded thicket strata of the green belt and 8 plots of $100 \mathrm{~m} \times 100 \mathrm{~m}$ are allocated for the green open space along the street. One subplot of $10 \mathrm{~m}$ $\times 2 \mathrm{~m}$ was also randomly selected from each of the $100 \mathrm{~m} \times 3 \mathrm{~m}$ plots and one subplot of $10 \mathrm{~m} \times 5$ m.

$$
\begin{aligned}
& \text { Procedures of Tree Measurement } \\
& d=\text { Girth } / \pi \ldots \ldots \ldots . . .7 \\
& \text { where: } \quad d=\text { diameter } \\
& \text { girth= tape measurement } \\
& \pi=3.14
\end{aligned}
$$

\section{Converting Tree Measurement to Aboveground Biomass}

The absorption ability of the trees is calculated according to size of the trees. The carbon dioxide absorption of the trees is calculated by the number of the trees $x$ unit per hectare $x$ constant of adsorption $x$ 24h.the formulas of carbon dioxide absorption by big, medium, and small trees are as follows.

$$
\begin{aligned}
& A b=n b \times u b \times 129.92 \times 24 \ldots \ldots . .8 \\
& A m=n m \times \text { um } \times 12.56 \times 24 \ldots \ldots . .9 \\
& \text { As }=\text { ns } x \text { us } \times 2.74 \times 24 \ldots \ldots \ldots . .10
\end{aligned}
$$


Carbon stock of Ashoka and Rain trees = number of trees $x$ constant $x$ (diameter) 2.62, and 2). Carbon stock of palm tree $=$ number of trees $x$ constant $x$ diameter $x$ height. They are formulated as follows:

$$
\begin{aligned}
& \text { Sar }=\mathrm{n} \times 0.0238 \times \mathrm{D} 2.62 \ldots \ldots \ldots .11 \\
& \mathrm{Sp}=\mathrm{n} \times 1.712 \times \mathrm{D} \times \mathrm{h} \ldots \ldots \ldots .12
\end{aligned}
$$

\section{Root Cause Analysis}

Simple root cause analysis is used to identify not only what and how an event occurs, but also why it happens. If the reason for an event or failure is determined, any possible remedial action that prevents future events of the observed type can be determined. There is a four-step process involved in root cause analysis, including data collection, charting causes, identification root causes, and generation of recommendations and implementation.

\section{RESULTS AND DISCUSSION Carbon Dioxide Emission}

The total amount of carbon dioxide emission from human activities in the shops, offices, restaurants, a hotel and a hospital and the combustion of fossil fuels from motorized vehicles reaches $123,481.916 \mathrm{~kg} /$ day (Table 1 ).

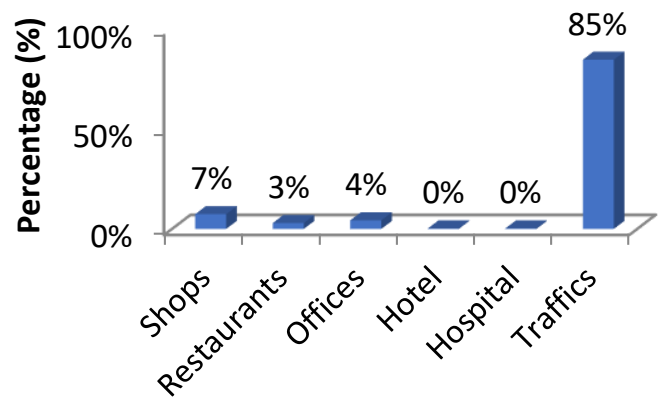

Figure 1. Carbon Dioxide Emission Percentage

The average rate of carbon emissions generated by human activities in the SoekarnoHatta road area is $11513.67 \mathrm{~kg} /$ ha per day. This has significantly less impact on environmental conditions. However, since this study focuses only on the number of people and their activities that are perceived as activities contributing lightly to carbon emissions, findings of human activity such as rest or low activity, normal work, and sleep activity show low levels of carbon emissions from human activity in the Soekarno-Hatta area. The carbon emissions from human activities in the
Soekarno-Hatta region show low $\mathrm{CO}_{2}$ levels. This is because there are only shops, restaurants, offices, hotels, and hospitals that contribute lower carbon emissions than factories that are hard work. In addition, the number of people performing activities affects the level of carbon emissions. The linkages between human activity and environmental degradation vary widely. This supported previous studies $[9,10]$. According to the two studies, the current level of human consumption, combined with growing populations, has a significant negative impact on the natural environment and contributes to climate change. Similarly elasticity of $\mathrm{CO}_{2}$ emissions and energy use to populations approached unity. This means that the size of the population alone does not significantly affect the level of $\mathrm{CO}_{2}$ in the air [9].

In addition, the results of the analysis of the amount of carbon emissions from motor vehicles on the Soekarno-Hata road show a significant amount of $\mathrm{CO} 2$ of $71.301 .89 \mathrm{~kg} /$ ha per day. This indicates that the rest of the process of burning fossil fuels for motor vehicles contributes significantly to $\mathrm{CO}_{2}$ emissions. Estimates of one ton / day carbon emissions on the Soekarno-Hatta road can be caused by the number of cars, motorcycles, trucks, and mini buses passing this road which has 4802 motor cycles per hour, 3887 hours per hour, 10 trucks per hour, 2 buses per Hour and 71 mini buses per hour. Apparently, these results support previous research conducted by Salam and Toshikuni who studied the relationship between human activity and $\mathrm{CO}_{2}$ emissions [11]. According to their research, in developing countries, significant human activities that cause increased $\mathrm{CO}_{2}$ emissions include: (i) burning of fossil fuels, (ii) the strength of terrestrial ecosystems and (iii) land-use change. Among these factors, the burning of fossil fuels is the most influential human activity for $\mathrm{CO}_{2}$ emissions in both developed and developing countries. The burning of fossil fuels has a significant positive effect on $\mathrm{CO}_{2}$ emissions in both developed and developing countries [11].

\section{Carbon Dioxide Adsorption}

Total Carbon dioxide adsorption by big, medium, and small trees is $802,610.630 \mathrm{~kg} / \mathrm{ha}$ per day $+82,933.756 \mathrm{~kg} / \mathrm{ha}$ per day $+57,196.028$ $\mathrm{kg} / \mathrm{ha}$ per day $=942,740.414 \mathrm{~kg} / \mathrm{ha}$ per day (Table 2). 
Table 1. Carbon dioxide Emission in Soekarno-Hatta

\begin{tabular}{lccccccc}
\hline \multicolumn{1}{c}{ Emission Source } & Shops & Restaurants & Offices & Hotel & Hospital & Traffics & Total \\
\hline Numbers (unit) & 127 & 52 & 41 & 1 & 1 & 8772 & \\
Amount in m3/day & 4632.96 & 1847.04 & 2692.04 & 151.944 & 177.744 & 104697 & 114198.728 \\
$\begin{array}{l}\text { Amount in kg/ha } \\
\text { per day }\end{array}$ & 2862.3 & 1141.12 & 1663.17 & 93.87 & 109.81 & 32717.81 & 38588.08 \\
\hline
\end{tabular}

Table 2. Carbon Dioxide Absorption in Soekarno-Hatta

\begin{tabular}{llcccc}
\hline \multicolumn{2}{c}{ Absorption } & Big Trees & $\begin{array}{c}\text { Medium } \\
\text { Trees }\end{array}$ & Small Trees & Total \\
\hline $\begin{array}{l}\text { Amount in } \mathrm{kg} / \mathrm{ha} \\
\text { day }\end{array}$ & per & 802610.63 & 82933.756 & 57196.028 & 942740.414 \\
\hline
\end{tabular}

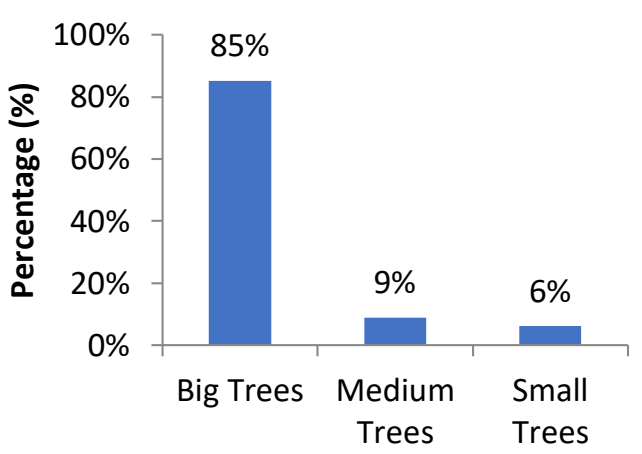

Figure 2. Carbon dioxide Absorption

The absorption of trees along the SoekarnoHatta street is calculated based on the number of small, medium, and large trees. The results of small tree analysis, 317 medium, and 217 big show the amount of carbon absorbed by these trees. With the area of Soekarno-Hatta road about 3.2 hectares, the carbon absorbed by trees in this area is as much as $942,740,414 \mathrm{~kg} /$ ha per day. This is considered a significant amount of absorption. Since the number of large tress on Soekarno-Hatta street is $60 \%$ per hectare of large trees, the number of medium trees on SoekarnoHatta street is $44 \%$ per hectare of medium trees and the number of small trees on Soekarno-Hatta street is $55 \%$ per hectare of trees Small, carbon absorption ability is also high considering most of the trees in 3.2hectare area of Soekarno-Hatta street. The amount of carbon sequestration of Soekarno-Hatta street trees is considered similar to nearly half a hectare of trees. Thus, it can be repeated that the carbon sequestration of Soekarno-Hatta's street trees is significant when compared to total $\mathrm{CO}_{2}$ emissions generated by traffic and human activities in this area and therefore trees should be considered an effective mechanism to offset $\mathrm{CO}_{2}$ emissions.
These results are in line with carbon sequestration standards in cities. A study conducted by Tang, Chen and Zhao found that the urban sequestration of urban trees in Beijing is half the equivalent of non-urban forests in China [12]. In addition, Davies et al. found that large amounts of carbon are deposited in top soil vegetation in Leicester, England, and the tree covers more than $95 \%$ of this carbon pool [13]. Furthermore, in some areas, in arid regions, urban forests can store more carbon than adjacent rural and suburban areas, as a result of tree planting and management of urban green space areas [14].

\section{Carbon Dioxide Balancing}

Carbon dioxide balancing is the calculation of total carbon dioxide emitted by human activities and motorized vehicles reduced by the total carbon dioxide absorbed by urban street trees on Soekarno-Hatta Street. As daily carbon dioxide emission from human activities and traffics reaches $78935.72 \mathrm{~kg} / \mathrm{ha}$ per day and the ability of the urban street trees to absorb carbon dioxide accounts for $942,740.414 \mathrm{~kg} / \mathrm{ha}$ per day, the balance between the emission and the absorption comes to $-863804.694 \mathrm{~kg} / \mathrm{ha}$ per day which means that the trees can effectively absorb carbon dioxide in the air. The negative result indicates that the trees still can absorb about 863804.694 $\mathrm{kg} /$ day more carbon dioxide emitted in the air. The result is presented in the figure below.

\section{Carbon Emission Transformation}

The carbon fraction in carbon dioxide is the weight ratio. The weight of carbon atoms is 12 units of atomic mass, while the weight of carbon dioxide is 44 , because it contains two oxygen atoms each weighing 16. 
Table 5. Problem and solution to reduce Carbon dioxide Emission and increase absorption

\begin{tabular}{|c|c|c|c|c|}
\hline No & Problems & $\begin{array}{c}\text { Roots of } \\
\text { Problems }\end{array}$ & Alternative Solution & Solution \\
\hline \multirow{3}{*}{1} & \multirow{3}{*}{$\begin{array}{l}\text { Carbon } \\
\text { dioxide } \\
\text { Emission }\end{array}$} & $\begin{array}{l}\text { Number of } \\
\text { People }\end{array}$ & $\begin{array}{l}\text { Limiting the number of } \\
\text { population living in an area } \\
\text { Restricting urbanization }\end{array}$ & $\begin{array}{l}\text { Limiting the number } \\
\text { of population living in } \\
\text { an area }\end{array}$ \\
\hline & & $\begin{array}{l}\text { Number of } \\
\text { transportation }\end{array}$ & $\begin{array}{l}\text { Reducing number of } \\
\text { motorized vehicles } \\
\text { Using more efficient fuel } \\
\text { Using public transportation }\end{array}$ & $\begin{array}{l}\text { Using more efficient } \\
\text { fuel }\end{array}$ \\
\hline & & $\begin{array}{l}\text { The age of } \\
\text { transportation }\end{array}$ & Doing regular maintenance & $\begin{array}{l}\text { Doing regular } \\
\text { maintenance }\end{array}$ \\
\hline \multirow[b]{2}{*}{2} & \multirow[b]{2}{*}{ Absorption } & $\begin{array}{l}\text { The fewer } \\
\text { number of } \\
\text { urban trees }\end{array}$ & $\begin{array}{l}\text { Planting more trees on the } \\
\text { sides of the urban streets }\end{array}$ & $\begin{array}{l}\text { Planting more trees } \\
\text { on the sides of the } \\
\text { urban streets }\end{array}$ \\
\hline & & $\begin{array}{l}\text { The number of } \\
\text { palm trees }\end{array}$ & $\begin{array}{l}\text { Making program on palm } \\
\text { tree plantation on the urban } \\
\text { streets and in housing areas }\end{array}$ & $\begin{array}{l}\text { Making program on } \\
\text { palm tree plantation } \\
\text { on the urban streets } \\
\text { and in housing areas }\end{array}$ \\
\hline
\end{tabular}

Thus, the ratio of molecular weight of carbon dioxide to carbon is $44 / 12$. This means that every $1 \mathrm{~kg}$ of carbon equals $3.67 \mathrm{~kg}$ of carbon dioxide [8]. Therefore, carbon dioxide emissions by human activities and motor vehicles in the Soekarno-Hatta road area are converted to carbon. The calculation is $78935.72 \mathrm{~kg} / 3.67=$ $21508.37 \mathrm{~kg} /$ ha per day. Total carbon emissions in the Soekarno-Hatta region are $21508.37 \mathrm{~kg} / \mathrm{ha}$ per day.

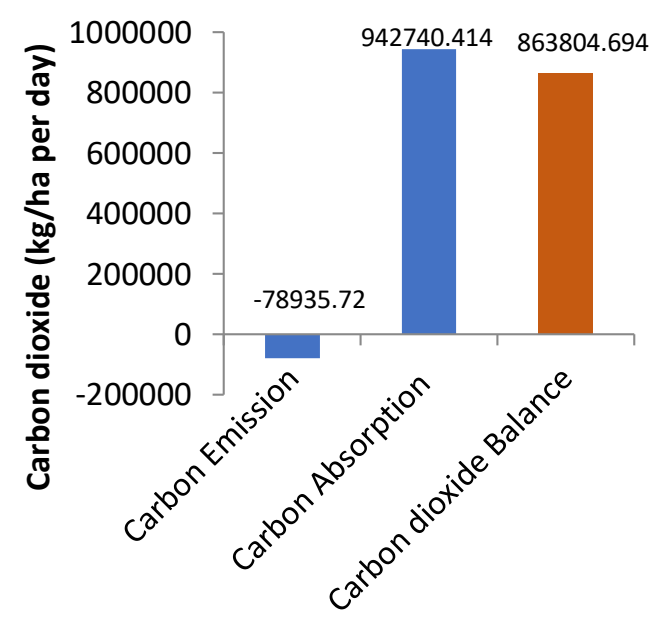

Figure 3. Carbon Dioxide Balance

The carbon fraction in carbon dioxide is the weight ratio. The weight of carbon atoms is 12 units of atomic mass, while the weight of carbon dioxide is 44 , because it contains two oxygen atoms each weighing 16 . Thus, the ratio of molecular weight of carbon dioxide to carbon is
$44 / 12$. This means that every $1 \mathrm{~kg}$ of carbon equals $3.67 \mathrm{~kg}$ of carbon dioxide [8]. Therefore, carbon dioxide emissions by human activities and motor vehicles in the Soekarno-Hatta road area are converted to carbon. The calculation is $78935.72 \mathrm{~kg} / 3.67=21508.37 \mathrm{~kg} /$ ha per day. Total carbon emissions in the Soekarno-Hatta region are $21508.37 \mathrm{~kg} /$ ha per day.

Table 3. Carbon Stock

\begin{tabular}{ccccc}
\hline Sources & $\begin{array}{c}\text { Ashoka } \\
\text { Trees }\end{array}$ & $\begin{array}{c}\text { Rain } \\
\text { Trees }\end{array}$ & $\begin{array}{c}\text { Palm } \\
\text { Trees }\end{array}$ & Total \\
\hline $\begin{array}{c}\text { Amount } \\
\text { in kg/ha }\end{array}$ & 0.004 & 0.168 & 378.877 & 379.049 \\
\hline
\end{tabular}

\section{Carbon Stock}

Total Carbon stock of trees on Sokarno-Hata Street is $1,212.955 \mathrm{~m} 3$. It is equal to $1,212.95511 / 1000=1.21295511$ ton or $1,212.95511 \mathrm{~kg}$. It is converted in to hectare as $1 \mathrm{~kg} / 3.2 \mathrm{ha}=379.0485 \mathrm{~kg} / \mathrm{ha}$.

The amount of carbon stock in palm trees in Soekarno-Hatta area is higher than Asoka tree ( $P$. longifolia) and Rain tree. Other study explored plant species diversity and carbon stock estimates, the findings indicate that among trees, the rubber tree, Hevea brasiliensis W., has the highest value index of allometric equations on carbon estimates followed oil palm tree or Elaeis guineensis L. and coconut or Cocos nucifera L. [15]. Other trees Has a much lower value index. This shows that the palm species have the ability to store more carbon than the Rain tree or Ashoka tree. However, since the number of palm trees is 
less than the extensive rainfall trees such as the Rain and Ashoka trees, the amount of carbon stock in the Soekarno-Hatta street area is also low. In addition, found that conversion of land to agriculture and housing causes degradation of carbon sequestration and carbon stocks [16]. The area of Soekarno-Hatta road is heavily densely seen by the number of people performing various activities in the Region, the level of carbon stock is also affected.

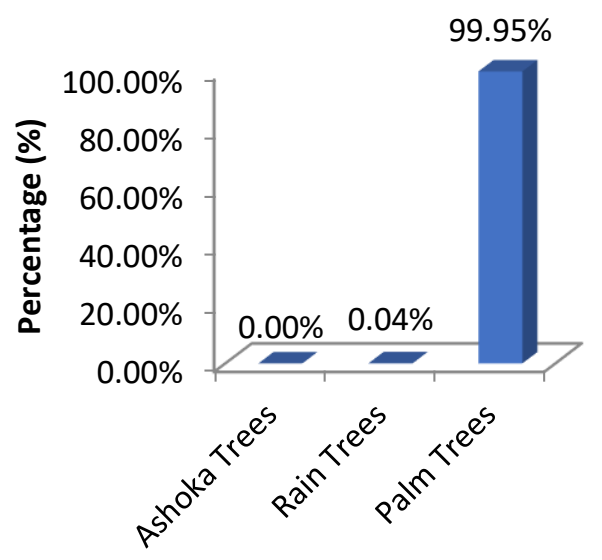

Figure 4. Carbon Stock

Moreover, Vesterdal et al. reported that forest floor $C$ stocks were higher for Coniferous (Pinus) types than agile forests (Betula and Populus) grown in temperate climates [17]. This explains the amount of carbon stock in the coconut trees compared to the Rain trees and Ashoka trees ( $P$. longifolia) because the leaves of the palm trees are more conifers than the broadleaved trees such as Rain trees and Ashoka trees.

To reduce the high emissions of carbon dioxide, this study recommend 4 solution. First solution was to reduce the number of population living in an area, followed by using more efficient fuel and doing regular maintenance. The second solution was to increase the number of plants and trees in the area, especially tree species such as palm trees and the number of motor vehicles to be controlled and the care and services is necessary to be performed periodically (Table 5).

\section{Carbon Balance of Emission and Stock}

The carbon balance is the amount of carbon after the calculation between carbon emission and carbon stock. It is obtained from carbon emission reduced by carbon stock. The formula is as follow.

- Carbon Balance = Carbon Emission Carbon Stock
- Carbon Balance $=10,514.468 \mathrm{~kg} / \mathrm{ha}$ daily - $379.04847 \mathrm{~kg} / \mathrm{ha}$ daily

Carbon Balance $=10,135.42 \mathrm{~kg} /$ ha daily

Table 4. Carbon Balance

\begin{tabular}{lccc}
\hline Carbon & $\begin{array}{c}\text { Carbon Emission } \\
\text { (kg/ha per day) }\end{array}$ & $\begin{array}{c}\text { Carbon } \\
\text { Stock } \\
\text { (kg/ha) }\end{array}$ & $\begin{array}{c}\text { Balance } \\
\text { (kg/ha) }\end{array}$ \\
\hline Amount & 21508.37 & 379.049 & 21129.32 \\
\hline
\end{tabular}

\section{CONCLUSION}

This study focuses on analyzing the carbon balance between carbon dioxide emissions generated by human activities including respiration and use of LPG and motor vehicles consisting of burning fossil fuels and drivers and passengers breathing and carbon absorption by urban street trees in the area of Soekarno-Hatta. Clearly, large amounts of carbon dioxide are emitted by motor vehicles compared to those generated by human activity. On the contrary, the city street trees which include Ashoka, Rain tree (Samanea saman), and Palm tree (R. regia) in Soekarno-Hatta area have considerable ability to absorb carbon emission, among which Palm tree (Palmam lingo) is able to absorb a large amount of CO. However, the carbon level in the SoekarnoHatta road area is not balanced because the amount emitted is higher than the stock found in the trees, but the area of Soekarno-Hatta road is not too polluted.

To reduce the high emissions of carbon dioxide, the number of plants and trees in the area has to multiply, especially tree species such as palm trees and the number of motor vehicles to be controlled and the care and services is necessary to be performed periodically.

\section{SUGGESTION}

It is predicted from the results of this study that $\mathrm{CO} 2$ emissions can be decreased by the reduction in the fossil-fuel consumption and alternate to other energy sources, to preserve the current forests, planting trees on abandoned and degraded lands, or by planting more urban street trees by society on urban street lands. Thus, it is recommended that the government and the community control the fossil fuel use as the major factor of the emissions of carbon dioxide and reduce them. In addition, the government should add an effective amount of trees to change emissions of carbon dioxide to become carbon stocks. 


\section{ACKNOWLEDGEMENT}

The author would like to thank to Director of Postgraduate School, and Head of Study Program Environment Resource Management Brawijaya University who were given permission for the research.

\section{REFERENCES}

[1]. John. H. 2009. Global Warming: The Complete Briefing. Cambride University Press.

[2]. Elosta, A. B., Leksono, A. S., \& Purnomo, M. (2013). People knowledge and perceptions about carbon dioxide (CO2) air pollution in Malang caused by motor vehicles. International Refereed Journal of Engineering and Science, 2, 46-51.

[3]. Streets, D. G., Bond, T. C., Carmichael, G. R., Fernandes, S. D., Fu, Q., He, D., Klimont, Z., Nelson, S. M., Tsai,N. Y., Wang, M. Q., Woo, J. H. and Yarber K. F. 2003. An inventory of gaseous and primary aerosol emissionsini Asia in the year 2000. J. Geophys. Res. 108:123.

[4]. Ninong, K. 2010. Variasi Temporal Konsentrasi karbondioksida (CO2) dan Temperature di Indonesia Berbasis Data Observasi Aqua-AIRS. Prosiding Seminar Nasional Sains Atmosfer I 2010. Bandung (in Indonesian).

[5]. Keenan, T. F. , I. C. Prentice, J. G Canadell, C. A Williams, H. Wang, M. Raupach \& G. J. Collatz. (2016). Recent pause in the growth rate of atmospheric $\mathrm{CO} 2$ due to enhanced terrestrial carbon uptake. Nat. Commun. 7, 13428.

[6]. Hofstad O (2005) Review of biomass and volume functions for individual trees and shrubs in southeast Africa. J Trop For Sci 17:151-162.

[7]. Goetz, S. J., Baccini, A., Laporte, N. T., Johns, T., Walker, W., Kellndorfer, J., Houghton, R. A., and Sun, M.: Mapping and monitoring carbon stocks with satellite observations: a comparison of methods, Carbon Balance Manage., 4, (2); 1-7. 2009.

[8]. USEPA 2017. Final Renewable Fuel Standards for 2017, and the Biomass-Based Diesel Volume for 2018

[9]. Dietz, T. EA. Rosa, \& R. York (2007) Driving the human ecological footprint Front Ecol Environ 5(1): 13-18

[10]. Myers, Norman \& Kent, Jennifer. (2003). New Consumers: The influence of affluence on the environment. Proceedings of the
National Academy of Sciences of the United States of America. 100. 4963-8.

[11]. Noguchi, T., \& Salam, M.A. (2007). Factors influencing the loss of forest cover in Bangladesh: An analysis from socioeconomic and demographic perspectives. Journal of Forest Research, 3, 145-150.

[12]. Tang, Y.J.; Chen, A.P.; Zhao, S.Q. Carbon storage and sequestration of urban street trees in Beijing, China. Front. Ecol. Evol. 2016, 4, 53.

[13]. Davies ZG, Dallimer M, Edmondson JL, Leake JR. Gaston KJ. Identifying potential sources of variability between vegetation carbon storage estimates for urban areas. Environmental Pollution. 2013;183:133-142

[14]. McHale, M. R., Burke, I. C., Lefsky, M. A., Peper, P. J., and McPherson, E. G. (2009). Urban forest biomass estimates: is it important to use allometric relationships developed specifically for urban trees? Urban Ecosyst. 12, 95-113.

[15]. Wiryono, Venny novia utami puteri, Gunggung senoaji. 2016. The diversity of plant species, the types of plant uses and the estimate of carbon stock in agroforestry system in Harapan Makmur Village, Bengkulu, Indonesia. B I O D I V E R S IT A S Volume 17, Number 1, 249-255

[16]. A S Leksono and A Afandhi R A F Gunawan. 2017. Land Use Change And Carbon Stock Dynamics In Tuban, East Java, Indonesia. Ecology, Environment and Conservation vol 23 no $171-76$.

[17]. Vesterdal, L., Ritter, E., Gundersen, P., 2002. Change in soil organic carbon following afforestation of former arable land. For. Ecol. Manage. 169, 137-143. 